Вісник Дніпропетровського університету. Біологія. Медицина. -2011. - Вип. 2, т. 1. - С. 3-11.

Visnyk of Dnipropetrovsk University. Biology. Medicine. - 2011. - Vol. 2, N 1. - P. 3-11.

УДК 639.311:597.551.2+[636.087.8+574.64]

О. В. Барбухо, А. О. Жиденко

Чернігівський національний педагогічний університет ім. Т. Г. Шевченка

\title{
ПІДВИЩЕННЯ ЖИТТЕЗДАТНОСТІ ЛИЧИНОК КОРОПА В УМОВАХ ДІї ГЕРБЩЦИДУ РАУНДАП ПРОБІОТИЧНИМ ПРЕПАРАТОМ БПС-44
}

Вивчено вплив гербіциду раундап (діюча речовина - ізопропіламінна сіль гліфосату, 480 г/л) у різних концентраціях на виживання личинок коропа (Cyprinus carpio L.). Показано можливість компенсації пробіотиком БПС-44 токсичної дії гліфосату. Раундап із концентрацією 0,01-80 мг/дм³ негативно впливас на личинок коропа. Попереднє гербіцидне навантаження впродовж пренатального періоду онтогенезу сприяс незначному зростанню життсдіяльності личинок лише за найменшої концентрації $\left(0,001\right.$ мг/дм $\left.{ }^{3}\right)$. В усіх інших випадках воно спричинює суттєве збільшення відходу личинок. Препарат БПС-44 сприяс підвищенню життсздатності личинок коропа, його найбільший ефект проявлясться за умов гербіцидного навантаження середньої інтенсивності $(0,02-0,80$ мг/дм³).

Е. В. Барбухо, А. А. Жиденко

Черниговский национальный педагогический университет им. Т. Г. Шевченко

\section{ПОВЫШЕНИЕ ЖИЗНЕСПОСОБНОСТИ ЛИЧИНОК КАРПА В УСЛОВИЯХ ДЕЙСТВИЯ ГЕРБИЦИДА РАУНДАП ПРОБИОТИЧЕСКИМ ПРЕПАРАТОМ БПС-44}

Изучено влияние гербицида раундап (действующие вещество - изопропиламинная соль глифосата, 480 г/л) в разных концентрациях на выживание личинок карпа (Cyprinus carpio L.). Показана возможность компенсации пробиотиком БПС-44 токсического действия глифосата. Раундап в концентрации 0,01-80 мг/дм ${ }^{3}$ отрицательно влияет на личинок карпа. Предшествующая гербицидная нагрузка в течение пренатального периода онтогенеза способствует незначительному возрастанию жизнедеятельности личинок лишь при наименьшей концентрации $(0,001$ мг/дм³). Во всех других случаях она приводит к существенно большему отходу личинок. Препарат БПС-44 способствует повышению жизнеспособности личинок карпа, его наибольший эффект проявляется в условиях гербицидной нагрузки средней интенсивности $\left(0,02-0,80\right.$ мг/дм $\left.{ }^{3}\right)$.

\author{
O. V. Barbukho, A. O. Zhidenko \\ T. G. Shevchenko Chernigiv National Pedagogical University

\section{ENHANCING THE VIABILITY OF CARP LARVAE BY PROBIOTIC PREPARATION BPS-44 UNDER THE HERBICIDE ROUNDUP INFLUENCE}

The influence of different concentrations of the herbicide roundup (active ingredient - izopropilamine salt of glyphosate, $480 \mathrm{~g} / \mathrm{l}$ ) on survival of the carp larvae (Cyprinus carpio $\mathrm{L}$.) and the compensation of the adverse effects by probiotic BPS-44 are studied. Roundup (concentrations from 0.01 to $80 \mathrm{mg} / \mathrm{dm}^{3}$ ) makes negative effect on the carp larvae. Primary herbicide stress in prenatal period of ontogenesis leads to some increase of larvae viability only in minimal concentration $-0.001 \mathrm{mg} / \mathrm{dm}^{3}$, in all other cases it leads to 
considerable increase of the larvae mortality. The preparation BPS-44 enhances the viability of carp larvae under conditions of medium toxic stress of the herbicide $\left(0.02-0.80 \mathrm{mg} / \mathrm{dm}^{3}\right)$.

\section{Вступ}

Значні масштаби застосування пестицидів для боротьби зі шкідливими організмами збільшили надходження цих речовин у водойми. Багато дослідників показали високу чутливість личинок риб до дії забруднювальних речовин, зокрема гербіцидів, які потрапляють у водне середовище та, навіть у невеликих концентраціях, згубно впливають на розвиток і виживання гідробіонтів [7; 14; 17], особливо на ранніх стадіях онтогенезу риб, призводячи до загибелі ікри та личинок, що, в свою чергу, впливає на процес відтворення та чисельність особин у популяції [2; 6].

Із метою підвищення виживання молоді риб на ранніх етапах онтогенезу в практиці рибного господарства широко застосовують пробіотики [5; 8]. На нашу думку, значного підвищення життєздатності личинок коропа в умовах токсичної дії гербіцидів можна досягти шляхом застосування пробіотичного препарату БПС-44. Цей препарат розроблено в Інституті сільськогосподарської мікробіології НААНУ (м. Чернігів), на основі живої культури мікробів Bacillus subtilis штаму 44-р, виділеного з рубця жуйних тварин, який володіє високою біологічною активністю. У зв'язку з позитивними результатами використання БПС-44 у тваринництві значний інтерес викликає ефективність застосування даного пробіотичного препарату для представників водної фауни, зокрема личинок риб, що зазнають гербіцидного навантаження.

Мета дослідження - охарактеризувати динаміку виживання личинок коропа лускатого, що перебували в умовах токсичного впливу гербіциду раундап, їх життєздатність під дією останнього з використанням пробіотичного препарату БПС-44.

\section{Матеріал і методи досліджень}

Експериментальний матеріал - личинки коропа лускатого (Cyprinus carpio L.), яких утримували в однолітрових акваріумах із відстояною водопровідною водою протягом 12, 24, 48, 72 і 96 годин. Досліди проводили у триразовій повторності. Середня температура води становила $+21,5^{\circ} \mathrm{C}$, концентрація кисню - 7,0-7,8 мг/л, $p H-7,5-8,4$. У різних варіантах досліду використовували по 100 личинок, перевезених із ВАТ «Чернігіврибгосп» у герметично закритих поліетиленових пакетах об'ємом 2 л, наполовину заповнених водою та киснем. Транспортування тривалістю 20 хв за температури води $+18{ }^{\circ} \mathrm{C}$ пройшло зі $100 \%$ виживанням личинок.

Варіанти досліду: 1) контроль; 2) вплив різних концентрацій раундапу 0,05 ГДК (гранично допустима концентрація) - 0,001 мг/дм ${ }^{3}, 0,5$ ГДК - 0,01, 1 ГДК - 0,02, 2 ГДК 0,04, 4 ГДК - 0,08, 40 ГДК - 0,8, 400 ГДК - 8,0 та 4000 ГДК - 80 мг/дм ${ }^{3}$ здійснювали тільки на личинок після їх вилуплення без попереднього впливу на ікру; 3 ) із попереднім впливом раундапу (в усіх визначених концентраціях) на ікру, а потім на личинок; 4) вплив пробіотичного препарату БПС-44 (ТУУ 24.4-00497360-691-2003) та різних концентрацій раундапу на личинок коропа без попереднього їх впливу на ікру, дію на личинок здійснювали тільки після їх вилуплення шляхом додавання до води (за добу до внесення раундапу) пробіотичного препарату БПС-44 з концентрацією мікроорганізмів Bacillus subtilis 44-p 1,25 × $10^{8}$ КУО/л води; 5) із попереднім впливом пробіотичного препарату БПС-44 та раундапу (в усіх визначених концентраціях) на ікру, потім їх спільна дія - на личинок. 
Відхід личинок в усіх варіантах досліду визначали шляхом прямого обліку. Одержані результати обробляли статистично за стандартними методами. Відмінності між групами вважали достовірними при $p<0,05$.

\section{Результати та їх обговорення}

Виживання личинок коропа за умов гербіцидного навантаження залежить як від використання певної концентрації раундапу, так і від того, чи піддавалися вони його впливу впродовж ембріонального розвитку, чи раундап почав впливати на личинок риб лише після їх вилуплення.

Через 12 годин дії на личинок коропа досліджуваного гербіциду в концентрації 0,001 мг/дм ${ }^{3}$ живими лишалися 90,9 \% особин, у концентрації $0,01 \mathrm{мг} /$ дм $^{3}-90,1 \%$, у концентраціях $0,02,0,04,0,08,0,8,8,0$ та 80,0 мг/дм ${ }^{3}-89,6,87,3,84,5,80,2,69,3$ та $0,0 \%$ відповідно. Пояснення цих результатів - фізико-хімічні властивості гліфосату, який добре розчиняється у воді, його коефіцієнт ліпофільності $\log P=-2,36 \pm 0,64$, що свідчить про високу швидкість проникнення цієї речовини до організму риб. На 12-ту годину експозиції в контрольній групі вижило 91,8 \% інтактних личинок (рис. 1).

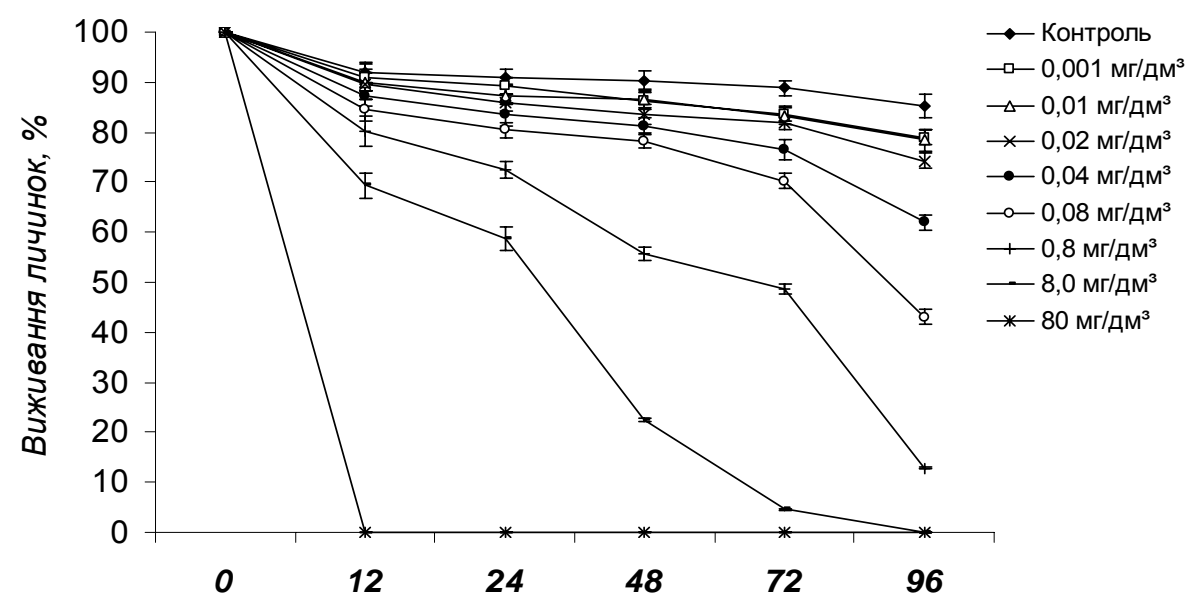

Тривалість експозиції, год.

Рис. 1. Вплив раундапу на виживання личинок коропа, які не піддавались його попередній дії $(M \pm m ; n=300)$

Щодо личинок, які піддавалися токсичній дії раундапу ще з ембріонального розвитку (рис. 2), то за його концентрації 0,001 мг/дм ${ }^{3}$ спостерігається виживання 91,4 \% особин, що більше за відповідне значення для тих личинок, ембріональний розвиток яких відбувався у чистій воді (90,9 \%). Можливо, це зумовлено тим, що низька доза гербіциду впродовж ранніх етапів онтогенезу сприяє активізації захисних і адаптаційних механізмів, за рахунок чого спостерігається деяке підвищення життєздатності личинок. Разом із цим, за вищих концентрацій токсиканта такого явища не спостерігається. За впливу раундапу у концентрації 0,01 мг/дм ${ }^{3}$ на личинок, що вилупилися у воді з відповідною його концентрацією через 12 годин експозиції, живими залишалися 82,5 \% їх початкової кількості, за концентрації гербіциду 0,02 мг/дм ${ }^{3}-82,4$ \%, за концентрацій $0,04,0,08$ та 0,8 мг/дм ${ }^{3}-78,9,74,7$ і 73,2 \% відповідно, тобто відхід личинок в 1,4-1,8 раза перевищував аналогічні значення для личинок з інтактної ікри, де їх виживання становило 91,8 \% (рис. 2). Можливо, перебування гідробіонтів у токсичному середовищі ще з ембріонального розвитку - фактор додаткового навантажен- 
ня, що посилює дію токсиканта на личинок коропа. Варіантів із личинками, ембріогенез яких проходив за концентрацій раундапу 8,0 та 80,0 мг/дм ${ }^{3}$, не було, оскільки за цих концентрацій 100 \% ікри загинуло на стадіях утворення очних бокалів і рухливості ембріонів в оболонках [1].

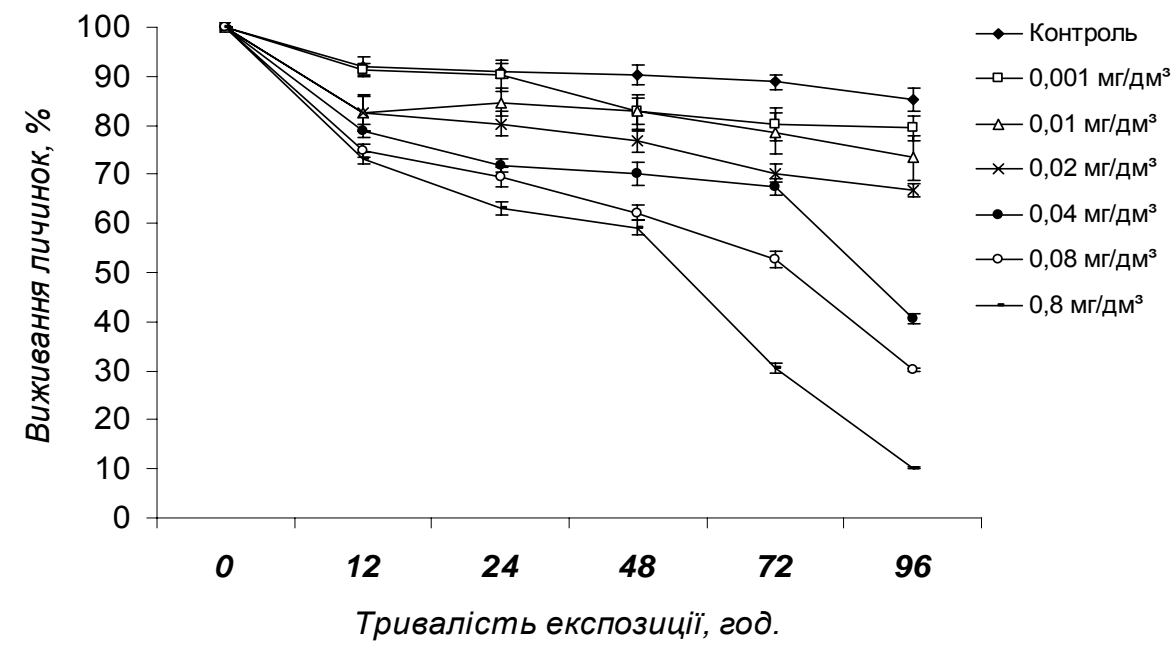

Рис. 2. Вплив раундапу на виживання личинок коропа, які піддавались його попередній дії $(M \pm m ; n=300)$

Через 24 години експозиції раундапу відбувалося поступове відмирання тих личинок, які впродовж ембріонального розвитку не піддавалися попередній дії гербіциду: за концентрацій токсиканту $0,001,0,01,0,02,0,04$ та 0,08 мг/дм ${ }^{3}$ їх виживання становило $89,2,87,3,86,0,83,5$ і 80,4 \% відповідно, тоді як інтактних личинок на цей час вижило 91,1 \%, тобто відмирання личинок після 12-годинної контрольної точки за цих концентрацій відбувалося паралельно 3 контролем (див. рис. 1). Разом із цим, за концентрацій досліджуваного гербіциду 0,8 та 8,0 мг/дм³ відмирання личинок у проміжку часу від 12 до 24 годин значно прискорилося порівняно 3 контролем - кількість особин, що вижили, складала лише 72,6 і 58,7 \% від їх початкової кількості. Динаміку виживання личинок коропа за дії раундапу в концентрації 80 мг/дм³ надалі не обраховували, оскільки впродовж першого облікового відрізку часу (12 годин) загинуло 100 \% личинок. Дія 80 мг/дм ${ }^{3}$ гербіциду більшою мірою вплинула на личинок, у результаті чого відбулась повна їх загибель (див. рис. 1).

У динаміці виживання личинок, що піддавалися попередній дії раундапу (впродовж ембріонального розвитку), через 24 години експозиції спостерігалися ті самі закономірності, що й через 12 годин. За концентрації токсиканта 0,001 мг/дм вижило трохи більше личинок порівняно з тими, що не піддавалися дії гербіциду на стадії ікри (90,2 порівняно з 89,2 \%). За концентрацій раундапу 0,01, 0,02, 0,04, 0,08 та 0,8 мг/дм ${ }^{3}$ живими залишалися $84,6,80,3,71,8,69,4$ та 63,1 \% особин відповідно, тобто частка відмерлих особин в 1,2-1,7 раза перевищувала частку відмерлих личинок, що не піддавалися попередньому гербіцидному навантаженню відповідної інтенсивності (див. рис. 2). Можливо, більша частка загиблих личинок залежала від кількості раундапу в ікрі, накопиченого протягом в онтогенезу.

Через 48 та 72 години експозиції ступінь виживання личинок, які не піддавалися попередній дії раундапу, так само залежала від концентрації токсиканта у воді. На кінець цих проміжків часу залишалося живими 90,3 та 88,8 \% інтактних особин 
відповідно, за досліджуваних концентрацій раундапу від 0,001 до 0,08 мг/дм ${ }^{3}$ частка личинок, що вижили через 48 годин експозиції, складала 78,3-86,3\%, а через 72 години - 70,3-83,7\%, тобто й надалі повільно знижувалася, що свідчить про низьку здатність личинок до захисту від дії агресивного середовища через відсутність захисної зовнішньої оболонки, що виконує функцію бар'єра для проникнення токсичних речовин. За концентрації гербіциду 0,8 мг/дм³ відхід личинок стрімко зростав: через 48 годин живими залишилося 55,6 \% особин. Через 72 години $-48,6 \%$; за концентрації 8,0 мг/дм ${ }^{3}$ більшість личинок коропа загинула: через 48 годин їх відхід склав 77,6 \%, а через 72 години експозиції раундапу - 95,4 \% (порівняно з 9,7 та 11,2 \% відходу у контролі відповідно). Одержані фактичні докази токсичної дії гербіциду раундап у різних концентраціях на виживання личинок риб разом із даними, отриманими в інших дослідах $[3 ; 11 ; 12]$, дають підстави стверджувати, що значна їх загибель пов'язана зі зміною проникності покривів тіла в онтогенезі і, як наслідок, надходженням отрути в організм (низька у ікри, оскільки ембріон контактує із навколишнім середовищем через оболонку; і висока у личинок, оскільки взаємодія із середовищем відбувається безпосередньо через поверхню їх тіла).

Через 96 годин експозиції досліджуваного гербіциду у концентраціях 0,001, 0,01, 0,02 i 0,04 мг/дм ${ }^{3}$ частки личинок, які вижили, складали 79,0, 78,4, 74,3 і 62,0\% відповідно порівняно 3 85,2 \% у контролі. Щодо концентрацій раундапу 0,08 i $0,8 \mathrm{мг} /$ дм $^{3}$, то за їх впливу процес відмирання личинок значно посилився: частка особин, що вижили, становила лише 43,1 і 12,9 \% відповідно, що, можливо, пов'язано 3 тривалішим часом перебування їх у воді з токсикантом. За концентрації токсиканта $8,0 \mathrm{Mг} /$ дм $^{3}$ через 96 годин експозиції відхід личинок становив $100 \%$, адаптація неможлива (див. рис. 1). Отримані результати підтверджують думку інших авторів про шкідливий вплив токсичних речовин на личинок риб із наступною фазою настання смерті за дії високих концентрацій токсиканта [4].

Щодо впливу попередньої експозиції досліджуваного токсиканта (упродовж ембріогенезу) на здатність до виживання личинок за умов гербіцидного навантаження, то починаючи 3 48-ї години після вилуплення личинок він уже був незначним, через що різниця у ступені виживання личинок коропа, що не піддавалися попередній дії раундапу, та тих, що піддавалися, поступово згладжувалася впродовж перших діб постнатального розвитку (див. рис. 2). Відхід личинок за дії раундапу в концентраціях від 0,001 до 0,8 мг/дм ${ }^{3}$ порівняно $з$ тими, що не зазнавали попередньої його дії, через 48 годин був більшим лише у $1,1-1,7$ раза, через 72 години - у 1,1-1,6 раза, через 96 годин - лише до 1,5 раза.

Отже, раундап у всіх використаних концентраціях $\left(0,01-80\right.$ мг/дм $\left.{ }^{3}\right)$ виявляє токсичну дію відносно личинок коропа, що супроводжується зниженням їх життєздатності вже у перші години після вилуплення з ікри. Попереднє гербіцидне навантаження впродовж пренатального періоду онтогенезу сприяє незначному зростанню життездатності личинок лише за найменшої використаної концентрації $\left(0,001 \mathrm{мг} /\right.$ дм $\left.^{3}\right)$. В усіх інших випадках воно призводить до суттєвого збільшення відходу личинок. Стимулювальний вплив низької концентрації раундапу на життєздатність личинок коропа може пояснюватися тим, що у відповідь на розвиток стресу в організмі гідробіонтів активуються біохімічні процеси, результат чого - посилення адаптаційних можливостей організму тварин, а відтак - зменшення частки особин, що гинуть унаслідок токсичної дії гербіциду. За більших концентрацій токсиканта адаптаційні зрушення для компенсації негативної дії стрес-фактора вже не виникають. 
Як препарат із потенційно адаптогенними властивостями ми використали пробіотик БПС 44 на основі штаму аеробних спорових бактерій, додаючи його до води за добу до внесення раундапу. Виявлено, що пробіотичний препарат БПС 44 проявляє суттєвий позитивний вплив на виживання личинок коропа за високої інтенсивності гербіцидного навантаження: як тих, що потрапляли у токсичні умови вже у постнатальному розвитку, так і тих, які на стадії ікри піддавалися дії досліджуваного токсиканта. У перших: при концентрації раундапу, що не перевищує 0,02-0,04 мг/дм ${ }^{3}$, спостерігається помірний вплив пробіотичного препарату БПС-44 на виживання личинок коропа: кількість загиблих особин менша на 1,5-5,0 \% порівняно із впливом відповідних концентрацій раундапу без його компенсації пробіотиком (рис. 3).

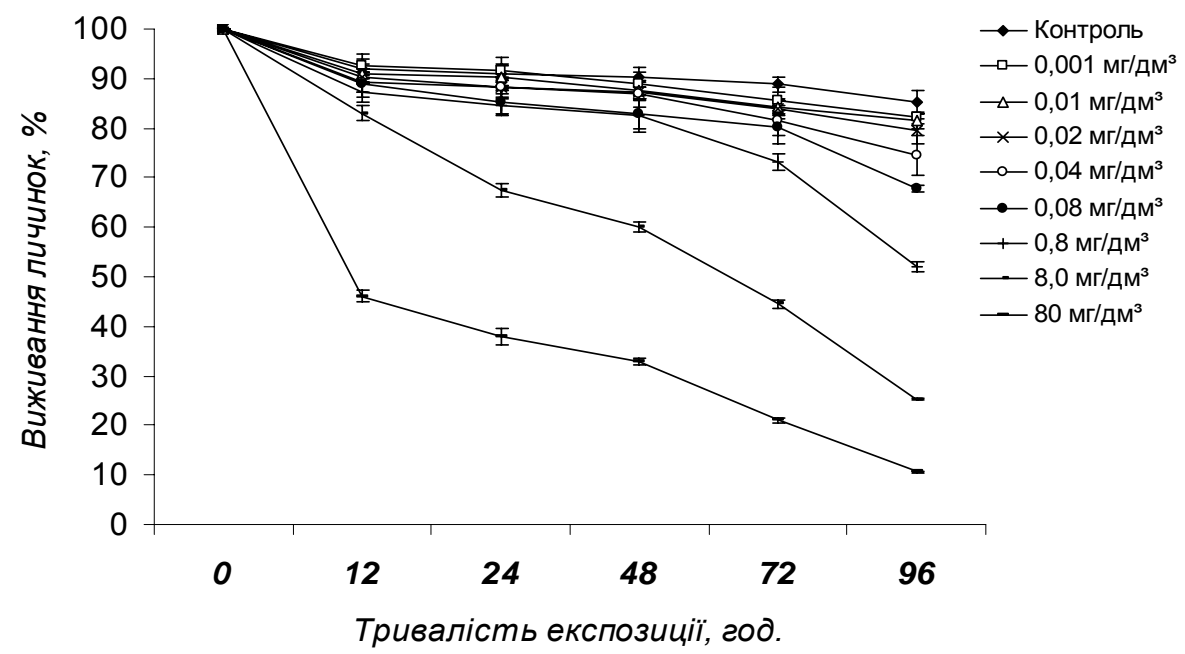

Рис. 3. Вплив пробіотичного препарату БПС-44 та раундапу на виживання личинок коропа, які не піддавались їх попередній дії $(M \pm m ; n=300)$

Лише через 96 годин експозиції за концентрації гербіциду 0,04 мг/дм³ спостерігається зменшення відходу личинок на 12,6 \% порівняно з відповідною контрольною точкою у варіанті без використання препарату БПС-44. Починаючи 3 концентрації раундапу 0,08 мг/дм ${ }^{3}$ і більше, за компенсації його токсичної дії пробіотичним препаратом ефект від застосування останнього проявляється більшою мірою, що, можливо, пов'язано з детоксикацією організму личинок завдяки дії бактерій Bacillus subtilis 44-p. За концентрацій токсиканта у воді 0,08, 0,8 і 8,0 мг/дм ${ }^{3}$ частка личинок коропа, що залишаються живими через 12 годин експозиції, склала 88,9, 87,1 і 83,0 \% відповідно, що на 5,2-19,3 \% перевищує їх виживання за дії лише раундапу. Через 24 години від початку експерименту живими залишалися 85,3, 84,6 і 67,5 \% відповідно, що на 6,016,5 \% більше, ніж без застосування пробіотика. Через 72 години - 80,2, 73,1 і 44,5 \% відповідно, що на 9,9-39,9 \% більше за відповідні концентрації раундапу, не компенсовані препаратом БПС-44 (див. рис. 1). Це узгоджується з відомостями про те, що додавання пробіотичних бактерій сприяє швидшому розкладанню шкідливих органічних речовин у воді, а також значно скорочує смертність личинок і мальків деяких риб [9; 10]. Ці процеси можуть бути пов'язані зі здатністю бактерій Bacillus subtilis виробляти низку органічних кислот (продуктів бродіння змішаного типу) і широкий спектр природних антибіотиків [15], за рахунок чого нормалізується склад мікрофлори макроорганізму, а відтак - підвищується життєздатність останнього. 
Через 96 годин частка живих личинок за концентрації гербіциду 0,08 і 0,8 мг/дм ${ }^{3}$ становила 67,7 і 52,0 \%, що в 1,6-4,0 раза більше, ніж у відповідних варіантах без пробіотика, за концентрації 8,0 мг/дм ${ }^{3}$ частка загиблих особин склала 74,7 \% порівняно зі 100,0 \% без додавання пробіотика. Отримані дані свідчать про те, що застосування пробіотиків сприяє підвищенню виживання личинок риб, зростанню їх стійкості до дії несприятливих факторів довкілля. За максимальної з використаних концентрацій токсиканта $\left(80,0 \mathrm{мг} /\right.$ дм $\left.^{3}\right)$ iз додаванням досліджуваного пробіотичного препарату, через 12 годин експозиції живими залишилося 30,3 \% особин, до 72-ї години експозиції їх кількість знизилася до 21,0 \%, до 96-ї години - до 10,6 \%. Проте за дії такої концентрації гербіциду без додавання у воду пробіотика БПС-44 всі личинки гинули впродовж перших 12 годин після потрапляння до токсичного середовища. Це, у свою чергу, узгоджується 3 даними Lara-Flores [16] щодо здатності пробіотичних бактерій зменшувати шкідливий вплив на личинок риб і підвищувати їх виживання за дії високих концентрацій токсиканта. Адже відомо, що одним із механізмів профілактичної дії пробіотичних препаратів на основі аеробних бацил вважається синтез мікроорганізмами ферментів, які каталізують гідролітичні та окисно-відновні реакції (оксидази зі змішаними функціями, низькоспецифічні естерази, епоксидгідролази тощо), за рахунок чого відбувається знешкодження токсичних органічних сполук [13].

Якщо порівнювати результати вивчення компенсаторної дії пробіотичного препарату БПС-44 за гербіцидного навантаження на личинок коропа, що виклюнулися 3 ікри, яка також піддавалася їх впливу, з вищенаведеними даними, то видно, що цей пробіотик також позитивно впливає на динаміку виживання личинок, як і у випадку, коли вони вперше поміщалися у воду з БПС-44 і раундапом лише на початку постнатального розвитку (рис. 4). Разом із цим, пробіотичний препарат також виявляє позитивний вплив на динаміку виживання личинок коропа, що перебувають у воді 3 концентрацією гербіциду, яка перевищує ГДК у 2-4 і більше разів. Це не дуже позначається на динаміці їх виживання у воді з нижчими концентраціями токсиканта. За компенсаторної дії пробіотичного препарату БПС-44 та мінімальної з використаних концентрацій гербіциду $\left(0,001\right.$ мг/дм $\left.{ }^{3}\right)$ не спостерігається помітної різниці у частці загиблих особин між виживанням личинок коропа, що піддавалися впливу раундапу та БПС-44 упродовж пренатального розвитку з тими, які зазнавали їх дії у перші години після виходу з ікри.

Щодо личинок, які піддавалися попередній дії БПС-44 із раундапом ще 3 ембріонального розвитку, то за його концентрації 0,01 мг/дм ${ }^{3}$ через 12 годин експозиції живими залишалися 90,5 \% від їх початкової кількості, за концентрації гербіциду 0,02 мг/дм ${ }^{3}-87,4$ \% (можливо, личинки, що залишилися, завдяки дії бактерій Bacillus subtilis 44-р набули стійкості до раундапу й у наступні дні практично не гинули), за концентрацій $0,04,0,08,0,8,8,0$ та 80,0 мг/дм ${ }^{3}-82,9,80,1,76,6,70,2$ і 40,3 \% відповідно, а отже, відхід личинок в 1,1-1,8 раза перевищував аналогічні значення для личинок з інтактної ікри.

У динаміці виживання личинок, що піддавалися попередній спільній дії раундапу з БПС-44 упродовж ембріонального розвитку, через 24 години експозиції спостерігалися ті самі закономірності, що й через 12 годин, проте за концентрації токсиканта 0,001 мг/дм³ вижило трохи менше личинок порівняно 3 тими, що не піддавалися попередній дії гербіциду з пробіотичним препаратом на стадії ікри (91,1% порівняно 3 91,5\%) (див. рис. 4). 


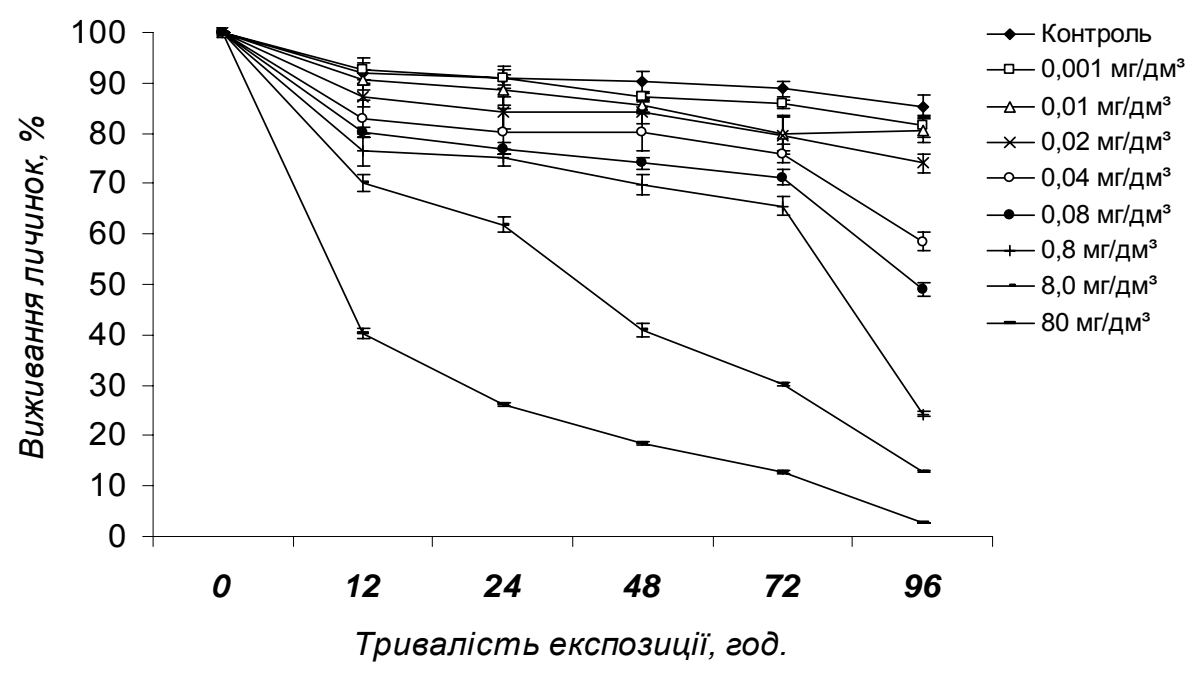

Рис. 4. Вплив пробіотичного препарату БПС-44 та раундапу на виживання личинок коропа, які піддавались їх попередній дії $(M \pm m ; n=300)$

Зі збільшенням терміну перебування личинок коропа у токсичних умовах, навіть за суттєвого позитивного впливу пробіотика БПС-44, кількість живих особин поступово зменшувалася, хоча і повільніше порівняно з варіантами без використання пробіотичного препарату. Щодо залежності життєздатності личинок гідробіонтів від того, чи перебувала їх ікра у токсичних умовах, простежується аналогічна закономірність, хоча різниця частки відмерлих особин дещо суттєвіша порівняно з відповідними варіантами без додавання у воду пробіотичного препарату.

Відхід личинок за дії раундапу в концентраціях 0,02-8,0 мг/дм³ порівняно 3 тими, що не зазнавали попередньої дії останнього за компенсаторного впливу пробіотичного препарату БПС-44, через 48 години експозиції був більшим в 1,2-1,7 раза, через 72 години - в 1,3-1,5 раза, через 96 години - в 1,4-2,2 раза.

Отже, за результатами дослідження впливу гербіцидного навантаження на виживання гідробіонтів і можливості підвищення ї життєздатності 3 використанням пробіотичного препарату БПС-44 встановлено, що раундап за дії всіх використаних концентрацій негативно впливає на личинок коропа. БПС-44 компенсує токсичний вплив гербіциду та сприяє підвищенню життєздатності личинок.

\section{Висновки}

Виживання личинок коропа залежить як від концентрації гербіциду раундап у воді, так і від того, чи піддавалися вони впливу токсиканта впродовж ембріонального розвитку, або пестицид почав впливати на личинок риб лише після їх вилуплення.

Раундап у концентраціях, що становлять 8,0-80 мг/дм³, характеризується високою токсичністю для личинок коропа. Пробіотичний препарат БПС-44 сприяє підвищенню їх життєздатності, його ефект найбільше проявляється за умов гербіцидного навантаження середньої інтенсивності $(0,02-0,8$ мг/дм³ $)$.

\section{Бібліографічні посилання}

1. Барбухо Е. В. Повышение жизнеспособности икры карпа при гербицидном зазрязнении пробиотическим препаратом БПС-44 // Биология внутренних вод. Тез. докл. XIV школы-конф. молодых ученых (Борок, 26-30 октября 2010 г.). - Борок, 2010. - С. 5. 
2. Велдре А. Токсическое воздействие нитритов на рыб / А. Велдре, М. Роома // Экология. 1990. - № 11. - С. 71-73.

3. Дехник Т. В. Ихтиопланктон Черного моря. - К. : Наукова думка, 1973. - 234 с.

4. До питання про якість води водойм рибогосподарського призначення та ії вплив на розвиток ікри коропа (Cyprinus carpio L.) / В. В. Цедик та ін. // Науковий вісник ЛНУВМБТ ім. С. З. Гжицького. - 2008. - Т. 10, № 4 (39). - С. 273-278.

5. Карасева Т. А. Влияние препарата «сухая бактериальная культура ацидофильной палочки» на здоровье и рост радужной форели / Т. А. Карасева, Н. К. Воробьева, М. А. Лазарева // Марикультура Северо-Запада России. Тез. докл. научн.-практ. конф. - Мурманск, 2000. - С. 22-23.

6. Худияш Ю. Н. Выживаемость икры карпа на ранних стадиях эмбриогенеза под воздействием $N$-оксида 2,6-диметилпиридина / Ю. Н. Худияш, А. С. Потрохов, О. Г. Зиньковский // Гидробиол. журнал. - 2003. - Т. 39, № 6. - С. 83-89.

7. Экологические аспекты биологии репродукции / Г. Г. Корниенко, А. А. Кожин, С. П. Воловик, Э. В. Макаров. - Ростов-на-Дону : Эверест, 1998. - С. 8-17.

8. Юхименко Л. Н. Перспективы использования субалина для коррекции микрофлоры кишечника и профилактики БГС / Л. Н. Юхименко, Г. С. Койдан, Л. И. Бычкова // Проблемы охраны здоровья рыб в аквакультуре. Тез. докл. науч.-практ. конф. - М. : МИК, 2000. - С. 10-13.

9. Administration of probiotic strain to improve sea bream wellness during development / O. Carnevali, M. C. Zamponi, R. Sulpizio et al. // Aquaculture Int. - 2004. - Vol. 12. - P. 377-386.

10. Current methodology for the use of probiotic bacteria in the culture of marine fish larvae / S. B. Kennedy, J. W. J. Tucker, M. Thomersen et al. // Aquaculture '98. Book of Abstracts. - 1998. - P. 286.

11. Development of swimming and feeding functions in larvae turbot, Psetta maxima, reared in the laboratory / H. Kohno, M. Moteki, K. Yoseda et al. // Turkish Journ. of Fisheries and Aquatic sciences. - 2001. - Vol. 1, N 1. - P. 9-15.

12. Khanaichenko A. N. Ways to improve turbot larvae rearing / A. N. Khanaichenko, Y. E. Bityukova, N. K. Tkachenko // From Discovery to Commercialization. Abstracts of contributions presented at the Intern. Conf. World Aquaculture'93. Torremolines : EAS Spec. publ. (Spain, May 26-28, 1993). Spain, 1993. - Vol. 19. - P. 399.

13. Removal of common Fusarium toxins in vitro by strains of Lactobacillus and Propionibacterium / H. S. El Nezami, A. Chrevatidis, S. Auriola et al. // Food Additives and Contaminants. - 2002. Vol. 19, N 7. - P. 680-686.

14. Rudneva I. I. The biochemical effects of toxicants in developing eggs and larvae of Black Sea fish species // Marine Environ. Res. - 1998. - Vol. 46, N 1-5. - P. 499-500.

15. Stein T. Bacillus subtilis antibiotics: Structures, syntheses and specific functions // Molecular Microbiology. - 2005. - Vol. 56, N 4. - P. 845-857.

16. Use of the bacteria Streptococcus faecium and Lactobacillus acidophilus, and the yeast Saccharomyces cerevisiae as growth promoters in Nile tilapia (Oreochromis niloticus) / M. Lara-Flores, M. A. Olvera-Novoa, B. E. Guzman-Mendez et al. // Aquaculture. - 2003. - Vol. 2 - P. 193-201.

17. Westernhagen H. Sublethal effects of pollutants on fish eggs and larvae // Fish Physiol. - 1998. Vol. 11. - P. 253-346.

Надійшла до редколегії 19.01.2011 